\title{
Religion and infectious diseases - review
}

P. Hajj Ali (Peri Haji Ali) $)^{1,2}$, V. Krcmery (Vladimir Krcmery)1,3, J. Polonova (Jarmila Polonova)2, J. Adamcova (Jana Adamcova)2, 5. Spanik (Stanislav Spanik)², M. Jankechova (Monika Jankechova)², N. Bujdova (Natasa Bujdova)2, P. Laca (Peter Laca)², A. Gallova (Andrea Gallova)², T. Bak (Tadeusz Bak)², T. Hrindova (Tatiana Hrindova) ${ }^{2}$, S. Subramanian (Selvaraj Subramanian) ${ }^{3}$

Original Article

${ }^{1}$ Saint Elizabeth University, Migrant Health Program, Erbil Autonomous Republic of Kurdistan

2 Tropic Team PhD MHA Program, Bratislava, Slovakia

${ }^{3}$ SEU Nutrition and Public Health Program Kuala Lumpur Malaysia

\section{E-mail address:}

tropicteam@gmail.com

\section{Reprint address:}

Monika Jankechova

Tropicteam

St. Lesley College, SEU

Nove Zamky, Slovakia

Suource: Clinical Social Work and Health Intervention

Pages: $29-34$

Volume: 8

Cited references: 15

Issue: 2

\section{Reviewers:}

Andrea Shahum

University of North Carolina at Chapel Hill School of Medicine, USA

Selvaraj Subramanian

SAAaRMM, Kuala Lumpur, Malaysia

\section{Key words:}

Mass gatherings, Religion, Infectious diseases (ID), Zoonoses (WHO defines zoonoses as diseases/infections naturally transmitted between vertebrate animals and humans. A zoonotic agent may be a bacterium, a virus, a fungus or other communicable disease agent).

\section{Publisher:}

International Society of Applied Preventive Medicine i-gap

CSWHI 2017; 8(2): 29 - 34; DOI 10.22359/cswhi_8_2_06 @ 2017 Clinical Social Work and Health Intervention 


\section{Abstract:}

This mini review analyzes the reason why many infectious diseases are rarely represented within the overall spectrum of ID in particular regions. The link between behavioral/cultural factors and the religion prevalent in those areas is analyzed. In addition outbreaks of infections in the community, linked to mass religious gatherings (Kumbh Mela, for Hindu, Haj for Muslims, and Urbi et orbi for Christians) is discussed.

\section{Conflict of interest:}

None.

\section{Introduction}

Religion and infectious diseases (ID) should have no linkage, however, our worldwide experience, as well as WHO statistics say, that some ID is rare in areas with a certain religion. In addition, seasonality has been observed in certain zoonoses and other vector borne ID (in relationship to seasonal religious events. Third, vice versa mass religious gatherings should be logically related due to a large number of pilgrims, to result in more outbreaks and small epidemics after religious holidays.

The aim of this mini-review is to analyze the potential relationship between infectious diseases on national or regional levels and the linkage of religious events to epidemics; additionally, the potential correlation between seasonality in zoonoses and other ID and religious factors.

\section{Religion per se and Occurrence of Infectious Diseases}

There is a large body of evidence that some IDs are very rare in countries where one religion is dominant. Islam is a good example but not the only one. Table 1 shows diseases which are very rare or much lower in Muslim countries in comparison to non-Muslim. The only question is in the proportion of the Muslim population which is pretecting the nation state or area from those diseases. One of the correlations known for hundreds of years as to the absence of the transmission sexual diseases (STI) is the type of cultural behavior leading to those diseases. For example there is no doubt that Hepatitis C, HIV, Trichomoniasis, Chlamydia Cervicitis, Gonorrhea and Syphilis are rare in countries with more than $80 \%$ of those linked to Islam. These include some 20 states with more than 1 billion population: Indonesia, Bangladesh, Malaysia, Brunei, Pakistan, Emirates, Iran, Afghanistan, Saudi Arabia, Libya, Algeria and Morocco. There are examples underlying this rule: India as a mix religious country; Turkey as a $95 \%$ Muslim country with secular behaviors of the younger generation; Egypt with several millions of other than Islam religious minorities; sexual crimes in Syria and Iraq with STI occurrence in war victims. Those four exceptions underline the rule that the Muslim model of family is extremely protective against the majority of STI, including Hepatitis $\mathrm{C}$ and HIV.

However, there are examples, that in such muslim prevalent type population countries, HIV may be neglected from the political/ religious/ medical reason. e.g. the epidemic of HIV transmission in Shimkent hospital in Kazakhstan and Osh in Kirghistan in 2004 and 2010, as well as the Bulgarian Nurses, event in Libya, are clear examples, that political protection of HIV absence may cause that a whole generation of medical students 
and practising doctors never seen (and never heard) e.g. HIV, hepatitis C, syphilis, gonorrhoea etc., and in case of emerging event caused by IV drug users importing those STI from non-Muslim environment to up to 100 Muslim countries will cause irreparable damage, how it was seen in Kazakh hospital in Shymkent, where the epidemics were under information and media ban, declared from the authorities as non-existing and majority of innocently infected children died. Political influence led also to a false accusation of contra religion such as in the Lybian case, when Bulgarian nurses were death-sentenced by Muammar Gaddafi ruled Lybian courts, as the culprit of HIV epidemics in children caused hovered not by bot-terrorists from US or unbelievers enemies, but contaminated haematology devices, similarly to Kazakhstan. In Kirgiztan, vice versa the Islamic state however with democratic rules of new secular government acted acted in very different way was inviting western experts to identify the epidemics in all three Kirgiz cities and led to the proper treatment of all cases including mothers and with legal consequences to irresponsible lab health care haematology workers.

STI is only one example, where the religious model of Muslim families led to only exceptional cases of several infections.

Another good example is foodborne infections will porcine zoonotic origin. Diseases transmitted or hosted by pigs are exceptional in Muslim countries or even areas with prevalent Islam population. A good example is India and Bosnia in Europe, here overall number e.g. of cysticercosis is not too much different from Asian average or European median, but the distribution of cysticercosis \{pig hosted tapeworm\} is solely linked to non-Muslim, e.g. Hindu, families or villages of Christian minorities.

Vice versa, zoonoses transmitted by sheep and goat, which is food used by the majority of Muslims, as meat or milk products, e.g.
Listeriosis, Q fever, Brucellosis are predominantly sensed among non-pork eaten Muslim enclaves e.g. In European Balkan, Bosnia, Albania, Kosovo as well as Maghreb Mediterranean states.

\section{Seasonality of ID and religion}

Several outbreaks are seasonal because of religious event and celebrations. End of Ramadan is in some Mediterranean countries linked to foodborne and waterborne diarrhoeal diseases, vice versa, Ramadan with the absence of foodborne pathogen related ID. Among Christian Catholics, feast in some countries led to the decrease of food born ID and allergies, however Chinese new year to increased number of foodborne trematode infections in China Singapore (Western Pacific), however quite linked to the Chinese communities. The third example is Eastern religious holiday among Christians, where Salmonellosis transmitted by contaminated eggs has seasonal spring peaks because eggs are extensively used from Easters souvenirs and gifts in central and eastern Europe.

\section{Mass religious gatherings and infections}

Several outbreaks are seasonal because of religious event and celebrations. End of Ramadan is in some Mediterranean countries linked to foodborne and waterborne diarrhoeal diseases, vice versa, Ramadan with the absence of foodborne pathogen related ID. Among Christian Catholics, feast in some countries led to the decrease of food born ID and allergies, however Chinese new year to increased number of foodborne trematode infections in China Singapore (Western Pacific), however quite linked to the Chinese communities. The third example is Eastern religious holiday among Christians, where Salmonellosis transmitted by contaminated eggs has seasonal spring peaks because eggs are extensively used from Easters souvenirs and gifts in central and eastern Europe. 
Three type of religious gatherings, at least have been linked to high risk of mainly gastrointestinal, respiratory ID and zoonoses Kumbh Mela in Ganga \{India\}, Hajj in Makkah \{Saudi Arabia\}, and Christmas Urbi et Orbit in Rome \{Italy\} for roman Catholics. Surprisingly, any of those mass religious gatherings represent an evident risk, of epidemics, despite many risk factors. Probably the protective effect of faith to the immune system may be responsible for protection against full blown clinically apparent $\{$ ID $\}$ (explanation for nonbelievers) and well organisation of health care, availability of health services and Gods or Saints protection explanation for believers may elucidate this mystery. Despite about 50 million pilgrims every year in India, Kumbh Mela 3 million at least, pilgrims at once in Makkah and 1 million in Rome during last papal elections, no serious outbreak of ID even gastrointestinal epidemics has been noted, also probably due to extensive and massive interference of health policy, trained heath care staff and clinics in designated pilgrimage areas. Despite e.g. in Hajj close contact (face to face) during the stoning of Satan, sharing sharp devices among million of those who are shaving their faces, and killing a million animals as sacrifice and offer the second and third day of Hajj, has not resulted in any significant increase of respiratory or CNS bacterial disease (zoonoses) or bloodborne ID, such as hepatitis B, hepatitis C and HIV epidemics in Makkah, Medina and even during follow-up.

\section{Conclusions/ Prevention and surveillance}

In conclusion lessons from local health authorities has to be taken when asking how preventable are outbreaks during mass religious gatherings. Concerted action of Indian Public Health National Service with local hospitals, volunteers and doctor religion organisations is one of the positive examples how can we effectively run a large religious event without danger to health or other nonreligious citizens and to other religious pilgrims during Kumbh Mela. Vaccinating and religious visa policy of Saudi Arabia is another example of the effective minimising risk of e.g. Meningitis transmission during Hajj and Influenza transmission after the event. Religion per se and religion driven family models are the evident and clear component against the spread of sexually transmitted ID such as hepatitis and HIV, as well as the zoonosis in post event activities after Hajj. Sanitary infrastructure, flexible supplementation of mobile toilets, safe water and volunteer/ driven mass of healthcare workers in Rome, successfully prevented ID outbreaks during three last papal elections in Rome.

Therefore religion seems in all three settings, lifestyle and family life, seasonality of events, and religious mass gatherings protective when combined with well established repressive visa system and state system \{Hajj Makkah\}, local preparedness (Kumbh Mela, India) and experience, linked to data from evidence-based medicine and scientific knowledge, more positive influence to the epidemiology of gastrointestinal, sexually transmited and respiratory infectious diseases outbreaks.

\section{References}

1. ALFELALI M, ALQAHTANI AS, BARASHEED O, BOOY R, RASHID, H (2016). Mandating influenza vaccine for Hajj pilgrims. Lancet Infect Dis. 2016; 16: 633-634 View in Article | Summary | Full Text | Full Text PDF | Scopus (1).

2. GAUTRET P, STEFFEN R (2016). Communicable diseases as health risks at mass gatherings other than Hajj: what is the evidence? (published online March 14.) Int J Infect Dis. 2016; DOI: http://dx.doi.org/10.1016/j. ijid.2016.03.007 View in Article | Summary | Full Text | Full Text PDF | Scopus (4). 
3. KIMULI D, MIKLOSKOVA M, SPANIK S, SUVADA J, CZARNECKI P (2016). Social Pathology II. Warszaw, Management University, 2016. pp.: 455.

4. BUJDOVA N (2015). Development and legal regulation of voluntary actvities in Slovakia. Aspects of cross-border cooperation in the field of volunteering. Liraprint Ukrajina, 2015, 194 s. ISBN 978-617-596-219-0.

5. BUJDOVA N (2015). The elimination of problematic behavior of childen in relation to the State Family Policy. SPAY, Social Pathology Among Youth. St. Elitabeth University of Health and Social Work Bratislava. 2015 s. 93. ISBN 978-80-8132-131-3.

6. POLONOVA J (2015). Respiratory infections after camping in free nature are the current diseases in Migrants to Austria and Germany via Hungary in September 2015: Experience from Roszke and Vamoszabadi. In Kremery V, Liskova A, Mrazova M, Herdics G, Khali I, Polonova J, Suvada J, Bucko L, Bibza M, Ondova P, Hajj P, Fer I. Clinical Social Work, 2015; 5(2 2015) 33-35. ISSN:2222-386X.

7. POLONOVA J (2015). Self-acceptance, self-esteem building and experiencing of healthy sexuality among youth as the prevention of an abuse in partnerships In Suvada, J. - Tomanek, P. (eds.), 2015. Social pathology among youth (abstract book). Bratislava: St. Elisabeth University of Health and Social Work Bratislava, 2015. ISBN 978-80-8132-131-3. 73 - $74 \mathrm{p}$.

8. 3. PAN AMERICAN HEALTH ORGANIZATION (2016). Special edition report. Regional update EW 22, 2016. Influenza and other respiratory virus. ((accessed June, 20, 2016).) Source:

9. http://www.paho.org/hq/index.php?option $=$ com_content $\& v i e w=$ article $\& i d=3352 \%$ 3A2010-influenza-situation-report\&catid= 2407\%3Ainfluenza-other-respiratory-viruses\&Itemid $=2469 \&$ lang $=$ en Date: June 15 , 2016 View in Article.
10. EUROPEAN CENTRE FOR DISEASE PREVENTION AND CONTROL (2016). Potential risks to public health related to communicable diseases at the Olympics and Paralympics Games in Rio de Janeiro, Brazil 2016. Stockholm. (accessed June 20, 2016). Source: http://ecdc.europa. eu/en/publications/Publications/Risk-assessment-mass\%20gathering-Rio-201610May2016.pdf Date: 2016 View in Article.

11. BELOVICOVA M, ADAMCOVA J, KAFKOVA J ET ALL (2017). Low incidence of MRSA among physiotherapy patients.Clin Soc Work Health Intervention, vol.8.2017,1,33-3. ISSN 2076-9741/Online.

12. UYEKI TM, ZANE SB, BODNAR UR ET AL (2003). Large summertime influenza A outbreak among tourists in Alaska and the Yukon Territory. Clin Infect Dis. 2003; 36: 1095-1102.

13. GAUTRET P, BENKOUITEN S, AL-TAWFIQ JA, MEMISH ZA, HAJJ (2016). Associated viral respiratory infections: a systematic review. Travel Med Infect Dis 2016, 14: 92-109.

14. WHO (2005). Health conditions for travellers to Saudi Arabia pilgrimage to Mecca (Hajj). Wikly Epidemiol Rec 2005, 80: 43132.

15. MADANI TA, GHABRAH TM (2007). Meningococcal, influenza virus, and hepatitis $B$ virus vaccination coverage level among health care workers in Hajj. BMC Infect Dis 2007, 7: 80

16. LANCET SERIES (2016). Mass gatherings 1-3, Lancet Vol. 388, 2016, 1136.

Table 1: Infectious diseases related with pork consumption,limited or absent in muslim countries

\section{a.zoonosis}

- Cysticercosis/Taenia solium

- Trichinella spiarlis Boor muscleworm 


\section{b.foodborne bacteria and viruses}

- Erisipelotrix rusiopathiae/swine roseola

- Salmonella choleraesuis

- Nipah swine plaegie

- Swine influenza

Table 2: Recommended vaccination before travel to Mass religiou gatherings

\section{I. respiratorz ilness related to owercrowding}

- Influenya szndrome/ Influenza trivalent vaccine

- Meningococca disease/ABC meningococcal vaccine

- Polzvalen Pneumococcal vaccine

- H Influenyae HiB or sexalanet booster DTP/HiB

II. gastrointestinal with water contamination and limited handhzgiene

- Anti cholera po.vaccine

- Hepatitis A

\section{III. shaving and other bloodborne procedures}

- Hepatitis B

- In malaria endoemic countries with higher HIV prevalence

- Iinsuspected contct HIV pls use chemoprophzlaxis, combo of 3 ARV for 1 month, start no later than $48 \mathrm{~h}$ aft exposure

- II in feber in malaria regon use standby tx for 3 days $\mathrm{Co} / \mathrm{Artem}$ (artemisin combination),o use prophzlaxis starting 2/7 dazs befor travel with mefloquin or atovaquoneproguanail or doxycycline 